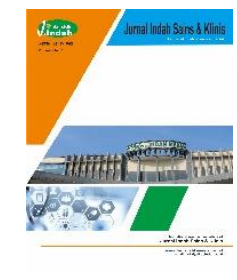

\title{
Efek Antihiperlipidemia Kombucha Daun Kari (Murraya koenigii (L.) Spreng) pada Tikus Putih Jantan (Rattus norvegicus) yang Diinduksi Dengan High Fat dan PTU
}

\author{
Hardyanto Napitupulu, Muharni Saputri *, Salmah Handayani Lubis, Muflihah Fujiko, Ernawaty \\ Ginting
}

Fakultas Farmasi, Program Studi Farmasi, Universitas Tjut Nyak Dhien, Medan, Indonesia Corresponding author: Muharnisaputri16@email.com

Received: 24 Oktober 2021; Revised: 29 Nopember 2021; Accepted: 1 Desember 2021

DOI: $10.52622 /$ jisk.v2i3.42

\begin{abstract}
Curry leaves (Murraya koenigii (L.) Spreng) is a plant that is often used in cooking spices that are high in fat because curry leaves contain secondary metabolite compounds such asalkaloids, glycosides, and flavonoids that serve to inhibit the growth of free radicals and lower cholesterol levels. Generally curry leaves are processed traditionally in a simple form, while research will process curry leaves in the form of fermented beverages in the form of kombucha tea. This study aims to explore the process of making curry leaf kombucha tea and know the antihiperlipidemia effect. This research is descriptive and experimental, including material collection, simplisia making, phytochemical screening, fermentation of curry leaf kombucha, evaluation of dosage quality, testing of triglyceride levels in rats with Electrode-Based Biosensor technique. The mice used in this study were 25 and divided into 5 test groups. K1 (negative blank), K2 (Simvastatin), K3 (dose $100 \mathrm{ml}$ ), K4 (dose $150 \mathrm{ml}$ ), K5 (dose 200 $\mathrm{ml}$ ) induced using $80 \%$ egg yolk and PTU $0.2 \%$. The results showed that the quality evaluation of kombucha tea gave good results to $\mathrm{pH}$ 3.08-3.44 and did not experience changes in taste and smell. In the group of 5 doses of $200 \mathrm{ml}$ with kombucha tea administration on the 7th to 15 th day, it was shown that cholesterol levels decreased from $253.0 \mathrm{mg} / \mathrm{dL}$ to $92.2 \mathrm{ml} / \mathrm{dL}$ where these results were close to comparing (simvastatin) from $247.8 \mathrm{mg} / \mathrm{dL}$ to $79.2 \mathrm{mg} / \mathrm{dL}$.
\end{abstract}

Keywords: hiperlipidemia, Elektrode-Based Biosensor, simvastatin, white rats

\begin{abstract}
Abstrak
Daun kari (Murraya koenigii (L.) Spreng) merupakan tanaman yang sering digunakan pada bumbu masakan yang tinggi lemak karena daun kari mengandung senyawa metabolit sekunder sepertialkaloid, glikosida, dan flavonoid yang berfungsi untuk menghambat pertumbuhan radikal bebas dan menurunkan kadar kolesterol. Umumnya daun kari diproses secara tradisional dalam bentuk sederhana, sedangkan penelitian akan mengolah daun kari dalam bentuk minuman fermentasi berupa teh kombucha. Penelitian ini bertujuan untuk mengetahui proses pembuatan teh kombucha daun kari dan mengetahui efek antihiperlipidemia. Penelitian ini bersifat deskriptif dan eksperimental, meliputi pengumpulan bahan, pembuatan simplisia, skrining fitokimia, fermentasi kombucha daun kari, evaluasi mutu sediaan, pengujian kadar trigliserida pada tikus dengan teknik Elektrode-Based Biosensor. Tikus yang digunakan dalam penelitian ini sebanyak 25 ekor dan dibagi menjadi 5 kelmpok uji. $\mathrm{K}_{1}$ (blanko negatif), $\mathrm{K}_{2}$ (simvastatin), $\mathrm{K}_{3}$ (dosis $100 \mathrm{ml}$ ), $\mathrm{K}_{4}\left(\right.$ dosis $150 \mathrm{ml}$ ), $\mathrm{K}_{5}$ (dosis $200 \mathrm{ml}$ ) yang diinduksi menggunakan kuning telur $80 \%$ dan PTU 0,2\%. Hasil penelitian menunjukkan bahwa evaluasi mutu teh kombucha memberikan hasil yang baik terhadap $\mathrm{pH}$ 3,08-3,44 dan tidak mengalami perubahan rasa dan bau. Pada kelompok 5 dosis $200 \mathrm{ml}$ dengan pemberian teh kombucha pada hari
\end{abstract}


ke-7 sampai hari ke-15 terbukti terjadinya penurunan kadar kolestrol dari 253,0 mg/dL menjadi 92,2 $\mathrm{ml} / \mathrm{dL}$ dimana hasil ini mendekati pembanding (simvastatin) dari $247,8 \mathrm{mg} / \mathrm{dL}$ menjadi $79,2 \mathrm{mg} / \mathrm{dL}$.

Kata Kunci: hiperlipidemia, Elektrode-Based Biosensor, simvastatin, tikus putih

\section{PENDAHULUAN}

Tahun 2005 sedikitnya 17,5 juta atau setara dengan 30\% kematian di seluruh dunia disebabkan oleh penyakit jantung. Di Indonesia, penyakit jantung juga cenderung meningkat sebagai penyebab kematian. Data survei Kesehatan Rumah Tangga (SKRT) tahun 1996 menunjukkan bahwa penyakit ini meningkat setiap tahun sebagai penyebab kematian mulai hanya 5,9\% pada tahun 1975 sampai 19\% pada tahun 1995. Sensus nasional tahun 2001 menunjukkan bahwa kematian karena penyakit kardiovaskular, termasuk penyakit jantung koroner (PJK) adalah 26,4\% dan sampai saat ini PJK merupakan penyebab utama kematian, yaitu sekitar 40\% kematian laki-laki usia menengah (1).

Kolesterol merupakan salah satu penyebab penyakit kardiovaskuler hingga aterosklerosis.Penyakit jantung aterosklerosis adalah pembunuh nomor satu bangsa Amerika setiap tahunnya sejak tahun 1921. Penyakit ini disebabkan penumpukan kolesterol dalam bentuk low density lipoprotein (LDL) di pembuluh darah yang menyumbat pembuluh darah jantung (2).

Etiologi aterosklerosis adalah multifaktorial tetapi ada berbagai keadaan yang erat kaitannya dengan aterosklerosis yaitu: hiperlipidemia, hipertensi, kebiasaan merokok, diabetes mellitus, olahraga, keturunan, dan stress. Hiperlipidemia merupakan suatu keadaan tingginya konsentrasi lipid yang ditandai dengan meningkatnya konsentrasi trigliserida, LDL (low density lipoprotein), dan kolesterol darah melebihi batas normal (pada manusia $>200 \mathrm{mg} / \mathrm{dl}$ ). Keadaan ini dapat ditimbulkan karena meningkatnya peroksidasi lipid yang disebabkan oleh radikal bebas di dalam tubuh, seperti organ hati (3).

Saat ini obat tradisional cukup banyak digunakan oleh masyarakat dalam usaha pengobatan sendiri (self-medication), tetapi pengemasan obat masih dalam bentuk ekstrak atau serbuk, sehingga penelitian ini bertujuan ingin mengemas sumber tumbuhan tradisional menjadi bentuk yang lebih menarik yang dibuat dalam bentuk minuman fermentasi berupa kombucha (4).

Teh kombucha adalah sebuah minuman hasil fermentasi yang dilakukan oleh SCOBY (Symbiotik Culture of Bacteria and Yeast). Substrat dalam pembuatan minuman kombucha dapat menggunakan dedaunan atau bahan yang mengandung senyawa fenolik tinggi, misalnya daun teh, daun kopi, daun sirih, dan semacamnya (5).

Proses fermentasi kombucha memerlukan waktu selama 7-14 hari. Dalam pembuatan kombucha gula gula berpengaruh terhadap keberlangsungan proses fermentasi. Gula merupakan sumber nutrisi bagi khamir dan bakteri yang dimanfaatkan selama proses fermentasi dan nantinya akan menghasilkan asam-asam organik (6). Asam-asam organik yang terkandung dalam kombucha yaitu asam folat, asam glokoronat, dan asam glukonat.Selain itu kombucha juga mengandung asam asam amino, asam asetat, asam usnic (berperan sebagai agen antibakteri), antibiotik serta vitamin(B1, B2, B3, B6, B12, dan C) (7).

Daun kari (Murraya koenigii (L.) Spreng)merupakan daun yang sangat familiar dan banyak di temukan hampir diseluruh wilayah Indonesia dan terkhususnya di Aceh, daun kari umumnya digunakan sebagai bumbu masakan karena akan memberikan citra rasa yang khas dan aroma yang kuat. Tanaman daun kari merupakan salah satu tanaman yang biasa digunakan sebagai obat tradisional masyarakat Indonesia (8).

Daun kari memiliki efek pada kesehatan, diantaranya dapat memberikan efek antikanker dan inflamasi, antidiabetes dan antibakteri. Daun kari sering dipakai sebagai bahan baku obat-obatan, yang berkhasiat untuk menyembuhkanberbagai penyakit seperti pusing-pusing, kulit gatal, gigitan serangga, sakit perut, rematik, dan gigitan ular (9).

Daun kari diketahui mengandung senyawa aktif seperti alkaloid, flavonoid, terpenoid, dan steroid. Keberadaan berbagai senyawa itulah yang membuat daun kari sangat bermanfaat untuk kesehatan.Tidak hanya itu, berbagai penelitian juga membuktikan kalau daun kari mengandung antioksidan seperti linalool, alpha-temene, myrcane, murrayanol, hingga alpha-terpinene. Sejumlah komponen ini dapat memerangi radikal bebas, untuk mencegah berbagai penyakit.Daun kari juga dapat membantu tubuh menurunkan kadar kolestrol dan trigliserida tinggi yang menjadi faktor penyebab penyakit jantung. Daun kari dapat diolah menjadi minuman dengan fermentasi menggunakan kultur kombucha sehingga dapat menghasilkan produksi yang baik dari kandungan teh daun kari tersebut 
sehingga dapat memberikan dampak yang positif dan memberikan manfaat yang baik bagi tubuh sebagai produk yang fungsional (9).

\section{METODOLOGI PENELITIAN}

\section{Alat-alat}

Alat-alat yang digunakan dalam penelitian ini adalah alat ukur kolestrol digital (easy touch multy®), Test Strips, oral sonde, spuit $5 \mathrm{ml}$, lemari pengering, loyang, kompor, panci steanless steel, sendok pengaduk dari kayu, saringan plastik, timbangan analog, serbet, karet gelang, toples kaca transparan, gelas ukur,batang pengaduk, dan stopwatch.

\section{Bahan-bahan}

Daun Kari (Murraya koenigii (L.) Spreng), aquadest, gula pasir, stater cair kombucha SCOBY, dan simvastatin.

\section{Penyiapan Hewan Uji}

Hewan percobaan yang digunakan adalah tikus putih jantan (Rattus norvegicus) yang sehat dan masing masing berat tikus $200 \mathrm{~g}$, berumur 2-3 bulan sebanyak 25 ekor. Tikus dibagi menjadi 5 kelompok, masingmasing kelompok terdiri atas 5 ekor tikus.Tiap tikus di adaptasikan selama 7 hari dan diberikan makanan dan minuman. Kemudian diukur kadar kolestrol awalnya lalu dibuat hiperlipidemia dengan cara memberikan makanan induksi kuning telur $80 \%$ yang diberikan, serta diberi pakan biasa lalu setelah 15 hari kolesterol tikus naik dan diukur.

\section{Pembuatan Simplisia Daun Kari}

Sebanyak $1000 \mathrm{~g}$ daun kari, di cuci dan dikeringkan di lemari pengering dengan suhu $500^{\circ} \mathrm{C}$. Setelah itu dihaluskan menggunakan blender. Kemudian simpan di tempat tertutup bersih dan rapi.

\section{Pembuatan Teh Kombucha Daun Kari}

Air bersih sebanyak $1500 \mathrm{ml}$ dimasukkan kedalam panci stainless yang telah diletakkan diatas kompor. Setelah air mendidih masukkan daun yang telah ditimbang sebanyak $30 \mathrm{~g}$ aduk sampai daun dan air menjadi menyatu. Tunggu sampai hangat kuku, saring dan masukkan kedalam toples kaca lalu tambahkan gula $150 \mathrm{~g}$ aduk sampai larut. Setelah dingin masukkan stater SCOBY pada teh daun kari. Tutup toples kaca yang berisi teh daun kari menggunakan serbet dan ikat menggunakan karet kemudian simpan di tempat gelap dan tidak goyang selama 14 hari. Setelah 14 hari dilakukanlah pemisahan minuman kombucha dengan scoby, dihasilkanlah kombucha daun kari $\pm 1000 \mathrm{ml}(10)$

\section{Formulasi Hasil dari Modifikasi teh Kombucha Daun Kari}

Tabel 1. Komposisi pembuatan formula modifikasi

\begin{tabular}{cc}
\hline Komposisi & Berat Bahan \\
\hline Simplisia Daun & 30 gram \\
Gula & 150 gram \\
Air & $1500 \mathrm{ml}$ \\
Stater Padat & 1 Lembar \\
\hline
\end{tabular}

\section{Penyiapan Sediaan Bahan Uji, Kontrol dan Obat Pembanding}

Percobaan efek penurunan kadar kolesterol terdiri dari beberapa tahap yaitu penyiapan bahan, penyiapan hewan uji yang hiperlipidemia dan pengujian efek penurunan kadar kolesterol. Penyiapan bahan-bahan meliputi larutan kuning telur bebek, suspensi propiltiourasil $0,2 \%$ blanko negatif, suspensi simvastatin (pembanding).

\section{Prosedur Pengujian Antihipertrigliserida}

Hewan di puasakan selama 24 jam, tidak diberi makan tetapi boleh minum tanpa batas. Pada hari pertama dilakukan pengujian kadar kolesterol awal diambil darah dari vena ekor tikus sebanyak $\pm 0,2$ 
$\mathrm{ml}$ dengan menggunakan alat pengukur kadar trigliserida. Tikus dibagi menjadi 5 kelompok masingmasing terdiri dari 5 ekor sebagai berikut:

$$
\begin{array}{ll}
\mathrm{K} 1 & \text { : Diberi pakan + lemak } 80 \%+\text { PTU } 2 \mathrm{mg} / \mathrm{kg} \mathrm{BB} \\
\mathrm{K} 2 & \text { : Diberi pakan + lemak } 80 \%+\text { PTU } 2 \mathrm{mg} / \mathrm{kg} \mathrm{BB} \\
\mathrm{K} 3 & \text { : Diberi pakan + lemak } 80 \%+\text { PTU } 2 \mathrm{mg} / \mathrm{kg} \mathrm{BB} \\
\mathrm{K} 4 & \text { : Diberi pakan + lemak } 80 \%+\text { PTU } 2 \mathrm{mg} / \mathrm{kg} \mathrm{BB} \\
\mathrm{K} 5 & \text { : Diberi pakan + lemak } 80 \%+\text { PTU } 2 \mathrm{mg} / \mathrm{kg} \mathrm{BB}
\end{array}
$$

Perlakuan dilakukan selama 7 hari, mulai dari hari pertama sampai hari ke 7. Kemudian hari ke 8 tikus kembali di puasakan tetapi tetap diberi minum dan hari ke9 dilakukan pengecekan kadar trigliserida pada tikus sekaligus pemberian sampel yang dilakukan setiap hari sebagai berikut:
K1 : Diberi blanko negatif
K2 : Diberi simvastatin
K3 : Diberi teh kombucha daun kari dosis $100 \mathrm{ml}$
K4 : Diberi teh kombucha daun kari dosis $150 \mathrm{ml}$
K5 : Diberi teh kombucha daun kari dosis $200 \mathrm{ml}$

Pengujian kadar trigliserida dilakukan sekali dua hari dan pemberian sampel dilakukan secara oral setiap hari sampai kadar trigliserida pada tikus turun.

\section{Analisis Data}

Data yang diperoleh dari hasil uji kolesterol total diuji secara statistic menggunakan uji KruskalWallis untuk melihat ada tidaknya perbedaan efek yang signifikan diantara seluruh bahan uji yang dilakukan, selanjutnya dilakukanuji BNT (Beda Nyata Terkecil) untuk melihat ada tidaknya perbedaan yang signifikan antara bahan uji satu sama lain (11).

\section{HASIL DAN PEMBAHASAN Pengujian Antihipertrigliserida}

Pengujian anti-hipertrigliserida dilakukan dengan metode Elektrode-Baset Biosensor yaitu metode yang memiliki prinsip katalis yang digabung dengan teknologi biosensor yang spesifik. Strip pemeriksaan dirancang dengancara tertentu sehingga pada saat darah diteteskan pada zona reaksi dari strip, katalisator kolesterol memicu oksidasi kolesterol dalam darah. Intensitas dari elektron yang terbentuk diukur oleh sensor dari alat dan sebanding dengan konsentrasi kolesterol darah (12).

Meningkatnya kadar trigliserida darah tikus dapat di sebabkan oleh pemberian kuning telur bebek $80 \%$ dan propiltiourasil $0,2 \%$ secara oral yang dilakukan selama 7 hari. Telur dapat meningkatkan kadar trigliserida dan trigliserida darah. Ini disebabkan kadar asam lemak jenuh yang tinggi didalam kuning telur bebek tersebut (13). Propiltiourasil dapat berkaitan dengan banyaknya protein. Karena adanya ikatan antara propiltiourasil dengan albumin menyebabkan proses metabolisme melebihi proses sintesisnya sehingga merangsang proses liposis dan pelepasan asam lemak bebas menyebabkan meningkatnya kadar trigliserida dalam darah.

Pemberian teh kombucha daun kari dengan dosis $200 \mathrm{ml}$. Penurunan kadar trigliserida darah tikus terlihat pada hari ke 15 terjadi secara signifikan. Dari ke-3 dosis ekstrak daun kari (Murraya koenigii (L.) Spreng), yang terbaik untuk menurunkan kadar trigliserida darah tikus yaitu dosis $200 \mathrm{ml}$ pada teh kombucha daun kari. Karena tidak berbeda dengan simvastatin konsentrasi 0,025\% pada hari ke 15 .

Data yang di peroleh dari hasil kadar trigliserida yang di uji secara statistik menggunakan uji Kruskal-wallis untuk melihat ada tidaknya perbedaan efek yang signifikan di antara seluruh bahan uji yang dilakukan, selanjutnya dilakukan uji Mann-Witney untuk melihat ada tidaknya perbedaan yang signifikan antara bahan uji satu sama lain.

\section{Hasil Pengukuran Uji Trigliserida}

Berikut adalah kadar Trigliserida rata rata setiap kelompok pada pemeriksaan awal, diet tinggi lemak dan setelah diberikan ekstrak :

Tabel 2. Hasil pengukuran uji trigliserida

\begin{tabular}{cccc}
\hline Kelompok & $\begin{array}{c}\text { Hari Ke 0 sebelum } \\
\text { perlakuan(mg/dL) }\end{array}$ & $\begin{array}{c}\text { Hari Ke 7setelah } \\
\text { pemberian kuning } \\
\text { telur (mg/dL) }\end{array}$ & $\begin{array}{c}\text { Hari Ke 15setelah } \\
\text { pemberian obat (mg/dL) }\end{array}$ \\
\hline
\end{tabular}




\begin{tabular}{lllc}
\hline $\mathrm{K}_{1}$ & 81,1 & 249,8 & 247,2 \\
$\mathrm{~K}_{2}$ & 76,2 & 247,8 & 79,2 \\
$\mathrm{~K}_{3}$ & 80,6 & 250,0 & 201,0 \\
$\mathrm{~K}_{4}$ & 87,2 & 253,4 & 161,5 \\
$\mathrm{~K}_{5}$ & 78,8 & 253,0 & 92,2 \\
\hline
\end{tabular}

Keterangan : $\mathrm{K}_{1}$ : blanko negatif

$\mathrm{K}_{2}$ : suspensi simvastatin

$\mathrm{K}_{3}$ : dosis $100 \mathrm{ml}$

$\mathrm{K}_{4}:$ dosis $150 \mathrm{ml}$

$\mathrm{K}_{5}: \operatorname{dosis} 200 \mathrm{ml}$

Berdasarkan Tabel 2 dapat dilihat bahwa hari ke 0 adalah kadar awal rata rata trigliserida dan di hari ke-7 kadar trigliserida meningkat karena diberikan pakan lemak dan di hari ke-15 kadar trigliserida menurun karena pemberian ekstrak daun kari dan selanjutnya digunakan uji Kruskal Wallis diperoleh perbedaan yang bermakna pada tiap kelompok yaitu nilai $\alpha(0,657) p$ value $>0,05$ dimana taraf kepercayaan yang digunakan 5\% $(0,05)$ maka, dapat disimpulkan bahwa terdapat perbedaan yang tidak signifikan antar kelompok pengujian terhadap kadar trigliserida.

Penurunan kadar kolestrol berhubungan dengan adanya senyawa metabolit sekunder yang terkandung di dalam daun kari diantaranya adalah flavonoid, tanin, dan glikosida. Senyawa yang diduga memiliki aktifitas menurunkan kadar kolestrol adalah senyawa flavonoid. Flavonoid bekerja sebagai inhibitor enzim HMG-CoA reduktase sehingga sintesis kolesterol menurun. Pada saat kolestrol di transport dari usus ke hati, maka HMG-CoA reduktase yang bertugas mengubah asetilcoA menjadi mevalonat dalam sintesis kolesterol akan terhambat sehingga produk sintesis kolestrol oleh hati akan berkurang. Senyawa lain yang diduga berperan dalam kolestrol yaitu tanin yang terkandung memiliki efek dalam menurunkan kolestrol sebagai antioksidan. Tanin bekerja dengan cara menghambat lipid dari saluran pencernaan yang mengganggu absorbsi lipid di dalam usus (3).

Dengan adanya kontrol positif dan kontrol negatif digunakan sebagai pembanding untuk mengetahui adanya pengaruh terhadap hewan percobaan kontrol negatif yang digunakan adalah kombucha tanpa simplisia, sedangkan kontrol positif simvastatin $10 \mathrm{mg} /$ hari sebagai pembanding karena mampu menurunkan kadar kolestrol total sebayak 20\% dan menurunkan penyakit penyumbatan pembuluh darah sebanyak 24\%. Simvastatin yang digunakan sebagai pembanding juga memiliki mekanisme anti kolestrol dengan menghambat secara kompetitif enzim HMG-CoA reduktase yang mempunyai fungsi sebagai katalis dalam penurunan kolestrol (3).

Berikut adalah hasil pengujian kadar trigliserida tikus yang mengalami peningkatan kadar trigliserida pada hari ke 7 setelah pemberian kuning telur dan PTU dilihat pada Gambar 1.

Berdasarkan Gambar 1 diatas dapat dilihat pada kelompok tikus putih yang diberi makanan hipertrigliserida memiliki rata rata kadar trigliserida yang tinggi, dan setelah diberikan perlakuan selama 7 hari, kadar trigliserida pada Kelompok 3, 4, 5, dan kelompok pembanding mengalami penurunan. Hal ini membuktikan bahwa pemberian teh kombucha daun kari dengan berbagai dosis dan pemberian obat simvastatin mampu menurunkan kadar trigliserida. Data yang diperoleh kemudian dianalisis secara statistika, digunakan Uji Kruskal-Wallis diperoleh data pada tiap kelompok yaitu nilai $\alpha(0,657) p$ value > 0,05 dimana taraf kepercayaan yang digunakan 95\% $(0,05)$ maka dapat disimpulkan bahwa terdapat perbedaan yang tidak signifikan antar kelompok pengujian terhadap kadar trigliserida, untuk mengetahui perbedaan antar masing masing kelompok dilanjutkan dengan uji MannWitney.

Peningkatan kadar trigliserida yaitu $249,8 \mathrm{mg} / \mathrm{dL}$ pada kelompok blanko negatif; $247,8 \mathrm{mg} / \mathrm{dL}$ pada control positif atau simvastatin;250,0 mg/dL pada Uji $1 ; 253,4 \mathrm{mg} / \mathrm{dL}$ pada Uji $2 ; 253,0 \mathrm{mg} / \mathrm{dL}$ pada Uji ke 3. Peningkatan kadar trigliserida pada penelitian ini terjadi karena pemberian pakan tinggi lemak. Kadar hiperkolesterolemia dapat dilihat dari adanya kenaikan kadar lipid yang terukur yaitu kadar kolesterol. Hasil ini dinyatakan sebagai kondisi hiperkolesterolemia. 


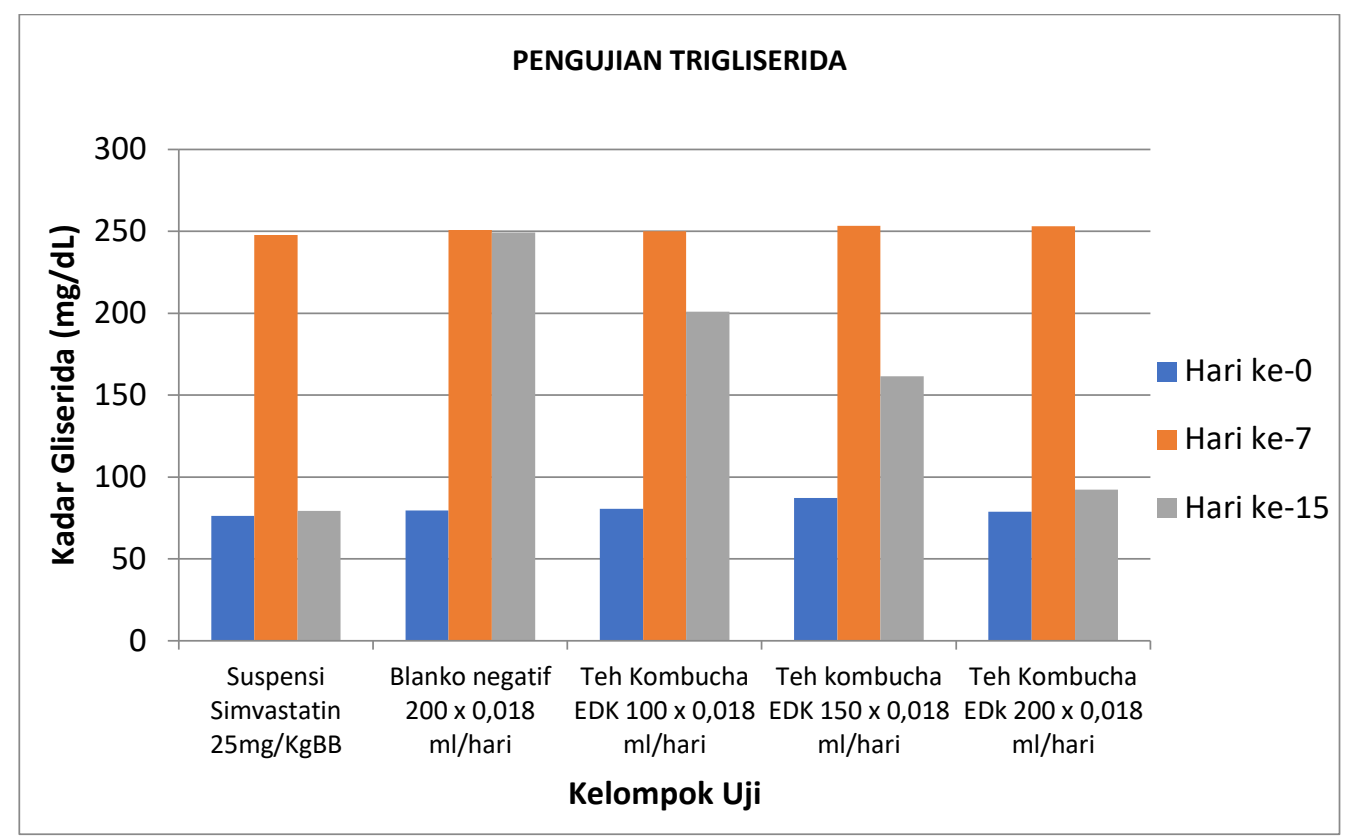

Gambar 1. Hasil Pengukuran Uji Trigliserida

Kuning telur terbukti efektif dalam peningkatan kadar trigliserida tikus putih yang ditunjukkan dengan tingginya kadar trigliserida post-test pada masing masing kelompok. Makanan dengan kadar lemak jenuh yang tinggi apabila di konsumsi secara terus menerus cendeerung meningkatkan kadar trigliserida dalam darah. Peningkatan kadar trigliserida serum Galur Wistar ini karena tingginya kandungan trigliserida dalam kuning telur bebek sehingga absorbsi trigliserida di usus menjadi meningkat (14).

Dari hasil pengukuran kadar trigliserida tikus selama 15 hari maka di lihat perbandingan penurunan kadar trigliserida tikus pada Gambar 2 berikut:

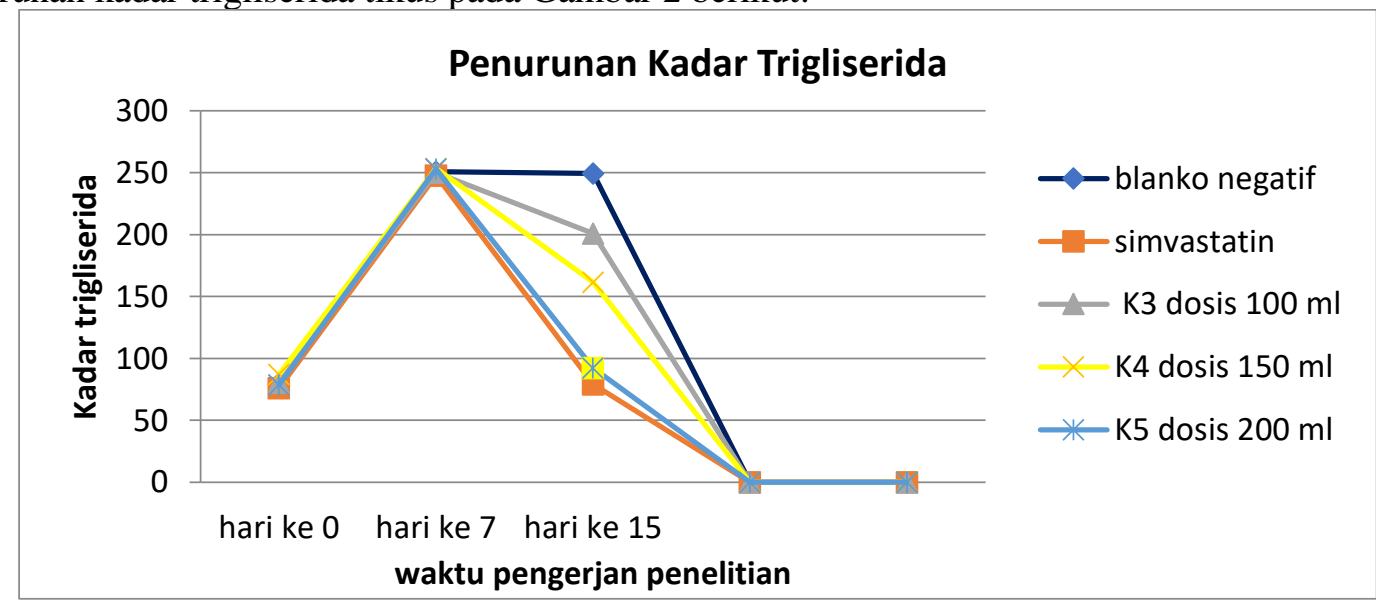

Gambar 2. Perbandingan penurunan kadar trigliserida tiap kelompok

Pemberian teh kombucha daun kari dengan dosis $200 \mathrm{ml}$ terjadi penurunan dengan rata rata kadar $92,2 \mathrm{mg} / \mathrm{dL}$ penurunan ini hampir sama dengan penurunan akibat memberikan obat simvastatin dan secara statistic terbukti sebanding. Sedangkan pada kelompok induksi setelah dilakukan pre test, kadar trigliserida meningkat. meningkatnya kadar trigliserida disebabkan karena kelompoknya ini hanya di berikan pakan biasanya dan kuning telur bebek tanpa adanya pemberian kombinasi ekstrak ataupun simvastatin. Hal tersebut membuktikan bahwa efek teh kombucha daun kari mampu menurunkan kadar trigliserida darah tikus putih.

Penurunan kadar trigliserida disebabkan karena kandungan senyawa kimia dalam daun kari seperti flavonoid yang berfungsi sebagai anti oksidan kuat yang mampu menghambat oksidasi trigliserida. Selain itu flavonoid mampu berkaitan dengan asam empedu dalam usus halus menjadi 
kompleks yang dikeluarkan melalui tinja sehingga tanpa asam empedu tersebut trigliserida tidak dapat diserap kembali oleh tubuh.

Hasil penelitian ini memiliki presentasi penurunan kadar trigliserida pada kelompok perlakuan pemberian teh kombucha daun kari dengan dosis daun kari 100 x 0,018=1,8 ml/hari $\left(\mathrm{K}_{3}\right)$ lebih kecil dibandingkan dengan kombinasi dosis lainnya. Hal tersebut dapat disebabkan oleh faktor lain, misalnya karena kondisi psikis stres, berat badan, dan metabolisme tikus yang dipakai dalam penelitian.

Tikus putih yang berjenis kelamin jantan memiliki kecepatan metabolisme yang lebih cepat dibandingkan dengan tikus betina.Selain itu, bermacam macam hormon yang di sekresi dapat mempengaruhi metabolisme trigliserida dalam darah, beberapa hormon yang berpengaruh pada metabolisme trigliserida adalah hormon pertumbuhsn, tiroid, epinefrin, norepinefrin, kortikotriopin dan glukotiroid.Semua hormon tersebut bersifat meningkatkan lipolysis (15).

Hasil penelitian menunjukkan bahwa kadar trigliserida pada darah tikus putih setelah pemberian teh kombucha daun kari lebih rendah dibandingkan pemberian teh. Hal ini menunjukkan bahwa pemberian teh kombucha secara signifikan dapat menurunkan kadar trigliserida darah tikus putih (3).

Statistik Kruskal Wallis adalah salah satu peralatan statistika non-parametrik dalam kelompokprosedur untuk sampel independen.Prosedur ini digunakan ketikakita ingin membandingkan dua variabel yang diukur dari sampel yangtidaksama (bebas), dimana kelompok yang diperbandingkan lebihdaridua (16).

Salah satu metode statistika non parametric yang setara dengan analisis ragam satu arah (one way anova) adalah uji Kruskal-Wallis.Uji ini bertujuan untuk menguji hipotesis bahwa beberapa sampel independen berasal dari populasi yang sama. Kesimpulan yang diperoleh dari uji Kruskal-Wallis apabila keputusan yangdiambil menolak $W H O$ adalah tidak semua populasi asal sampel sama. Untuk mengetahui populasi-populasi mana yang berbeda dapat dilakukan perbandingan berganda (17).

Uji rank Mann-Whitney adalah salah satu bentuk pengujian dalam analisis statistika non parametrik, dimana pengujian digunakan untuk menguji kesamaan distribusi dua populasi yang saling bebas dengan asumsi distribusi dari kedua populasi adalah kontinu dan skala pengukuran dari data minimal ordinal (18).

\section{KESIMPULAN}

Pemberian teh kombucha daun kari memiliki efek yang dapat menurunkan kadar kolesterol pada tikus putih jantan. Pemberian teh kombucha daun kari $\mathrm{K}_{5}$ dosis $200 \mathrm{ml}$ memperlihatkan penurunan kadar trigliserida darah pada tikus putih yang hampir sama dengan efek pemberian suspensi simvastatin. Penurunan kadar trigliserida ini terlihat jelas pada pemeriksaan hari ke-15.

\section{DAFTAR PUSTAKA}

1. Arief, M. I., Novriansyah., Riky., Budianto, I. T., Bimo, M. H. (2012). Potensi Bunga Karamunting (Melastoma malabathricum L) terhadap Kadar Kolesterol Total dan Trigliserida pada Tikus Putih Jantan Hiperlipidemia yang Diinduksi Propiltiourasil. Jurnal Prestasi. 1(2): 110-120.

2. Ferry, A. (2015). Perbandingan Efektivitas Daun Mengkudu dan Daun Binahong terhadap Penurunan Kadar Glukosa Darah Mencit (Mus musculus). Skripsi. FKIP Unpas Bandung.

3. Nuralifah., Wahyuni., Parawansah., Shintia, U. D. (2020). Uji Aktivitas Antihiperlipidemia Ektrak Etanol Daun Notika (Arcboldiodendron calosericeum Kobuski) terhadap Kadar Kolesterol Total Tikus (Rattus norvegicus) Jantan Galur Wistar. Jurnal Syifa Sciences and Clinical Research. 2(1): 1-8.

4. Suhardini, P. N dan Zubaidah, E. (2016). Studi Aktivitas Antioksidan Kombucha dari Berbagai Jenis Daun selama Fermentasi. Jurnal Pangan dan Agroindustri. 4(1): 229-237.

5. Akbar, B. (2010). Tumbuhan dengan Kandungan Senyawa Aktif yang Berpotensi sebagai Bahan Antiferilitas. Jakarta: Adabia Press. Halaman 4-6.

6. Yulistira, N. V. (2017). Pengaruh Proporsi Kulit Apel dan Konsentrasi Gula terhadap Karakteristik Fisik, Kimia dan Aktivitas Antioksidan Kombucha dari Kulit Apel. Skripsi. Universitas Brawijaya. 
7. Wulandari, A. (2014). Aktivitas Antioksidan Kombucha Daun Kopi (Coffea arabica) dengan Variasi Lama Waktu Fermentasi dan Konsentrasi Ekstrak. Skripsi. Universitas Muhammadiyah Surakarta.

8. Diana, F., Ukhty, N., Ajurullah. (2018). Pengaruh Pemberian Ekstrak Daun Kari (Murraya Koenigii) untuk Mengobati Benih Ikan Patin Siam (Pangasianodon hypophthalmus) yang Terinfeksi Bakteri Staphylococcus aureus. Jurnal Akuakultura. 2(2): 41-50.

9. Fauziah dan Surwanto. (2012). Perbedaan Kadar Trigliserid pada Penderita Diabetes Melitus Tipe 2 Terkontrol dengan Diabetes Melitus Tipe 2 tidak Terkontrol. Jurnal Kedokteran dan Kesehatan. 12(3): 32-41.

10. Purnami, K. I., Anak, A. G. N. A. J dan Ni, W. W. (2018). Pengaruh Jenis Teh terhadap Karakteristik Teh Kombucha. Jurnal Ilmu dan Teknologi Pangan. 7(2):1-10.

11. Hidayat, M., Soeng, S., Prahastuti, S., Patricia, T.H. dan Yonathan, K.A. (2014). Aktivitas Antioksidan dan Antitrigliserida Ekstrak Tunggal Kedelai, Daun Jati Belanda Serta Kombinasinya. Jurnal Ilmu-ilmu Hayati dan Fisik.16(2):19.

12. Suwandi, D. (2015). Perbandingan Hasil Pemeriksaan Kadar Kolesterol Total Metode Electrode-Based Biosensor dengan Metode Spektrofotometri. Jurnal Kedokteran. 1(1): 1-9.

13. Tjay, T. H, dan Rahardja, K. (2007). Obat-obat Penting: Khasiat, Penggunaan dan Efek-Efek Sampingnya. PT. Elex Media Komputindo. Gramedia, Jakarta. Halaman 537, 540 - 541, 545.

14. Yessirita, N.,Abbas, M. H., Heryandi, Y., Dharma, A. (2015). Peningkatan Kualitas Telur Itik Pitalah dengan Pemberian Pakan Tepung Daun Lamtoro. Jurnal Peternakan Indonesia. 17(1): 54-62.

15. Pujiatiningsih, A. D. (2014). Pemberian Ekstrak Daun Putri Malu (Mimosa pudica Linn) secara Oral Menurunkan Kadar Gula Darah Post Prandial pada Tikus (Rattus norvegicus) Jantan Jalur Wistar. Tesis. Fakultas BiodemikUniversitas Udayana.

16. Junaidi. (2010). Statistika Non-Parametrik. Skripsi. Fakultas Ekonomi Universitas Jambi.

17. Nawangsari, T. (2013). Perbandingan Berganda Sesudah Uji Kruskal-Wallis. Prosiding Seminar Nasional Matematika dan Pendidikan Matematika. Skripsi. FMIPA Universitas Negeri Yogyakarta.

18. Yanti, S. T. (2011). Uji Rank Mann-Whitney Dua Tahap. Jurnal Statistika. 7(1):55. 